\title{
Tuber Growth and Quality of Potato var. Kufri Bahar as Affected by FYM, Vermicompost and Neem Cake under Western Haryana Conditions, India
}

\author{
Mohamed Taha $^{1,2 *}$, T.P. Malik ${ }^{1}$, A.K. Bhatia ${ }^{1}$ and Sumit Deswal ${ }^{1}$ \\ ${ }^{1}$ Department of Vegetable Science, CCS Haryana Agricultural University, India \\ ${ }^{2}$ Horticulture Department Faculty of Agriculture, Minoufiya University, Egypt \\ *Corresponding author
}

\section{A B S T R A C T}

Field investigation was carried out to study the effect of integrated nutrient management on growth and yield parameters in potato var. Kufri Baharunder Western Haryana condition during 2015-2017. The experiment was laid out in a randomized block design with twelve nutrient management practices organic manures, viz. farmyard manure (FYM),

\section{Keywords}

Potato, Organic manure, Vegetative growth, Tuber yield.

\section{Article Info}

Accepted: 28 October 2017 Available Online: 10 December 2017 vermicompost (VC), neem cake (NC) and their combinations with inorganic fertilizers. Growth parameters like plant height, number of leaves per plant, number of stems per plant, fresh and dry weight of leaves per plant and yield attributing parameters like fresh and dry weight of tuber per plant and total yield per hectare increased with the application of vermicompost in different combination rates with inorganic fertilizer was much better than applying of neem cake one and the using of farmyard manure with them in tries combinations were the most effective treatments comparing with the others. However, highest values for number of tuber per plant and per plot as well as tuber yield per plot and per hectare was recorded on application of fertilizer mixture of $50 \%$ recommended nitrogen $+25 \%$ recommended nitrogen through FYM @ $7.5 \mathrm{t} / \mathrm{ha}+25 \%$ recommended nitrogen through VC @ $2.25 \mathrm{t} / \mathrm{ha}$ was the most effective treatment followed by $75 \%$ recommended nitrogen $+25 \%$ recommended nitrogen through VC @ 2.25t/ha, respectively. The highest dry matter $(18.84 \%)$ and maximum specific gravity (1.093) was recorded on application of $50 \%$ recommended nitrogen $+25 \%$ recommended nitrogen through FYM @ 7.5 t/ha + 25\% recommended nitrogen through VC @ 2.25 t/ha.

\section{Introduction}

Potato (Solanum tuberosum L.) plays a vital role in food security for ever increasing world population (Thiele et al., 2010 and Scott and Sourez, 2012). Potato has a high nutritional value because it is a rich source of protein, vitamin C, carbohydrate and iron (Banu et al., 2007). Potato can be highly productive, but it has a shallow root system and often requires adequate nutrient input to maintain tuber productivity and quality. Thus, for achieving higher productivity and quality, the use of nitrogenous fertilizers is increasing, which is leading to the increase in cost of production and also deterioration of soil as well as environmental pollution (Diacono and Montemurro 2010; Singh et al., 2007). However, a growing consciousness of the adverse impacts of inorganic fertilizers on crop production as well as increasing environmental and ecological concerns has 
induced greater interest in the utilization of organic amendments for crop production. Organic manures act not only as a source of nutrients and organic matter, but also increase microbial diversity and activity in soil, which influence soil structure and nutrients rotation, in addition to improvement in other physical, chemical and biological properties of the soil (Albiach et al., 2000; Edmeades, 2003), it also as slow motion source of plant nutrients to the crops and increases water holding capacity to preserve the water regime of the soil and acts as a buffer against change in soil pH (Upadhayay and Singh,2003). Thus, organic amendments/manures are environmentally benign and help in maintaining soil fertility as well as agricultural productivity. But organic farming alone may not meet the requirements of agricultural productivity and solve food and other problems. Proportionate combination of organic and inorganic sources of plant nutrients has been found to be the best option for increasing productivity and maintaining sustainability in crop production. Integrated nutrient management involving combination of organic manure and chemical fertilizers is an essential tool for balanced fertilization and sustainability of crop production on long term basis, as well as improves physical, chemical and biological properties of the soil besides improving fertilizer use efficiency and crop yield (Hegde and Dwivedi, 1993). As no single source is capable of supplying the required amount of plant nutrients, integrated use of all sources of plant nutrients is a must to supply balanced nutrition to the crops (Arora, 2008). There is need to develop and demonstrate balanced use of organic manures and chemical fertilizers not only to increase crop productivity but also to recycle the precious national resources and minimize the environmental damage and help in maintaining soil fertility as well as agriculture productivity. Among various organic products, vermicompost, neem cake and farmyard manure have been applied as organic supplementation in this experiment. Thus, there is a lot of potential use of organic manures in potato production. Keeping all these views, the present investigation was carried out to study the effect of integrated nutrient management on vegetative growth, tuber quality and total yield ha ${ }^{-1}$.

\section{Materials and Methods}

During Rabi season 2015-2017 an organic potato experiment with three organic sources was established on an experimental farm of the Department of Vegetable Science, Chaudhary Charan Singh, Haryana Agricultural University, Hisar, India $\left(29^{\circ}\right.$ $10^{\prime} \mathrm{N}, \quad 75^{\circ} \quad 46^{\prime} \mathrm{E}$ and altitude 215.2 mabovemeansea level). The study area lies in the semi-arid zone, characterized by severe cold in winter with hot and dry summer. The experiment was set up in three replications with each plot $\left(12.96 \mathrm{~m}^{2}\right)$ in a randomized block design. Each plot was 3.60 meters wide and $3.60 \mathrm{~m}$ long. There were 6 rows in all potato plots. All seed tubers were presprouted. Tubers were kept for 25-30 days before planting in sufficiently humid and lighted room in a wooden box. Seed tubers with a diameter of $35-55 \mathrm{~mm}$ were planted according to the norm of 2.5-3.0 $\mathrm{t} \mathrm{ha}^{-1}$ (52.910 tubers per hectare). The distance between tubers was $20 \mathrm{~cm}$, and the distance between rows $60 \mathrm{~cm}$. The domestic early to medium 'Kufri Bahar' potato cultivar was used. Seed tubers was sown in last October and harvested in the month of January in all the two years. The soil of the experimental farm is luvisol (Table 1), according to the World Reference Base classification (FAO, 2014), and the texture of the soil is sandy loam soil with a humus layer of 20-30 cm (Reintam and Koster, 2006).Nutrient management practices were Control; $100 \%$ recommended dose of nitrogen (RDN) through FYM; 100\% RDN through Vermicompost (VC);100\% RDN 
through Neem cake (NC); $75 \%$ RDN + 25\% RDN through FYM; $75 \%$ RDN + 25\% RDN through VC; $75 \%$ RDN + 25\% RDN through $\mathrm{NC} ; 50 \% \mathrm{RDN}+25 \%$ RDN through FYM + $25 \%$ RDN through VC; $50 \%$ RDN $+25 \%$ RDN through FYM + 25\% RDN through NC; $50 \% \mathrm{RDN}+25 \% \mathrm{RDN}$ through $\mathrm{VC}+25 \%$ RDN through NC; $25 \%$ RDN $+25 \%$ RDN through FYM + 25\% RDN through $\mathrm{VC}+$ $25 \%$ RDN through NC and full recommended NPK (150:50:100 kg ha-1) through inorganic fertilizer. FYM $30 \mathrm{t} \mathrm{ha}^{-1}$, VC $9 \mathrm{t} \mathrm{ha}^{-1}$ and $\mathrm{NC}$ $3 \mathrm{t} \mathrm{ha}^{-1}$ were used to supply $100 \%$ RDN (150 $\mathrm{kg} \mathrm{N} \mathrm{ha}{ }^{-1}$ ) for potato in this area. The nutrient composition of organic manures is presented in Table 2. Well decomposed farmyard manure, vermicompost and neem cake were incorporated into the top $15 \mathrm{~cm}$ of soil in the whole experimental bed (Arancon et al., 2003; Najar and Khan, 2013). Half dose of nitrogen and full dose phosphorus and potassium through urea, single supper phosphate and muriate of potash (MOP) were applied as basal dressing. The remaining half dose of nitrogen was top dressed at earthing up operation. All the necessary cultural practices and plant protection measures were followed uniformly for all the treatments during the entire period of experimentation.

\section{Growth and yield parameters}

For the growth and yield attribute parameters, five plants in each plot were tagged randomly in the second row of either north or south side in the field. Plant height, number of stems and number of leaves per hill after 90 days of sowing, fresh and dry weight of leaves and tubers at maturity stage were recorded. The crop was dehaulmed first and after one week, digging of potato was done manually. At harvest time, all tubers of each plot were harvested to record total yield $\mathrm{kg}_{\mathrm{plot}}{ }^{-1}$ and total yield per hectare. Dry matter percentage of tubers were determined by drying a subsample of $200 \mathrm{~g}$ fresh weight from each plot, theses tubers tissues were then cut into small pieces and dehydrated in a hot air oven at $70^{\circ} \mathrm{C}$ under vacuum till constant weight in order to determine the per cent dry matter. The specific gravity of tuber was obtained from the weight of sample unit in air divided by weight of sample unit in water.

\section{Statistical analysis}

The analysis of variance methods (Panse and Sukhatme, 1985) was followed to statistically analyze the various data. The significance of different sources of variations was tested by Error mean square of Fisher Snedecors F test at probability level $(\mathrm{P}=0.05)$.

\section{Results and Discussion}

Data presented in Table 3show the effect of organic and inorganic $\mathrm{N}$-fertilizers as $\mathrm{N}$ sources either each alone or in mixture of different replacement rate from FYM, VC and $\mathrm{NC}$ on plant growth attributes. The data declared that fertilization with any of organic sources either alone or in mixture forms significantly augmented the investigated above ground potato plant organs comparing to control. Integrated use of $50 \%$ recommended dose of $\mathrm{N}$ through inorganic fertilizer and remaining 50\% recommended dose of $\mathrm{N}(\mathrm{RDN})$ through organic sources (FYM, VC or NC) recorded the highest plant growth characters i.e. plant height, number of leaves and stems/plant and fresh weight of leaves and tubers/plant which were not significantly with $100 \%$ recommended dose of NPK through inorganic fertilizers followed by application of $75 \% \mathrm{RDN}+25 \% \mathrm{RDN}$ through VC during two years. The highest plant height, number of leaves and stems/plant and fresh weight of leaves and tubers/plant were obtained with the application of $50 \%$ RDN $+25 \%$ RDN through $\mathrm{FYM}+25 \% \mathrm{RDN}$ through VC, which were at par with the crop receiving $50 \% \mathrm{RDN}+25 \%$ 
RDN through FYM $+25 \%$ RDN through NC or $50 \% \mathrm{RDN}+25 \% \mathrm{RDN}$ through $\mathrm{VC}+25 \%$ RDN through NC. The results emphasized the need of integrated use of $50 \% \mathrm{RDN}$ through inorganic nitrogen and remaining 50\% through organic sources for producing highest growth characters of potato plant under north India condition.

Obtained growth enhancement owing to the above-mentioned treatments is in agreement with the results reported by Gawish et al.,
(2012); Kumar et al., (2012) and Atul Jayapal et al., (2016) on potato. The augmentation of plant growth parameters by vermicompost may not only be nutritional, but also due to its content of biologically active plant growthinfluencing substances (Warman and AngLopez 2010). The presence of plant growth regulators such as auxins, gibberellins, cytokinins of microbial origin (Tomati et al., 1988) and humic acids (Atiyeh et al., 2002) has been reported in vermicompost.

Table.1 Physico-chemical properties of soil of experimental field

\begin{tabular}{lccc}
\hline Properties & Measured value & Properties & Measured value \\
\hline Texture & Sandy loam & Available $\mathrm{N}\left(\mathrm{kg} \mathrm{h}^{-1}\right)$ & 142.00 \\
$\mathrm{pH}$ & 8.00 & Available $\mathrm{P}\left(\mathrm{kg} \mathrm{ha}^{-1}\right)$ & 18.00 \\
$\mathrm{EC}\left(\mathrm{dS} \mathrm{m}^{-1}\right)$ & 0.28 & Available K $\left(\mathrm{kgha}^{-1}\right)$ & 311.00 \\
Organic carbon $(\%)$ & 0.75 & & \\
\hline
\end{tabular}

Table.2 Average nutrient of different organic manures

\begin{tabular}{lccc}
\hline Organic Manures & $\mathbf{N}(\boldsymbol{\%})$ & $\mathbf{P}(\boldsymbol{\%})$ & $\mathbf{K}(\boldsymbol{\%})$ \\
\hline FYM & 0.58 & 0.49 & 0.51 \\
Vermicompost & 1.61 & 1.40 & 0.90 \\
Neem Cake & 2.02 & 0.91 & 2.14 \\
\hline
\end{tabular}

Table.3 Effect of integrated nutrient management on growth attributes of potato

\begin{tabular}{|c|c|c|c|c|c|c|c|c|c|c|}
\hline \multirow[t]{2}{*}{ Treatments* } & \multicolumn{2}{|c|}{$\begin{array}{l}\text { Plant height } \\
(\mathrm{cm})\end{array}$} & \multicolumn{2}{|c|}{$\begin{array}{l}\text { Number of } \\
\text { leaves/plant }\end{array}$} & \multicolumn{2}{|c|}{ Number of stems/plant } & \multicolumn{2}{|c|}{$\begin{array}{c}\text { Fresh weight of leaves } \\
\left(\text { g plant }^{-1}\right)\end{array}$} & \multicolumn{2}{|c|}{$\begin{array}{l}\text { Fresh weight of tubers } \\
\qquad\left(\mathrm{g}_{\text { plant }}{ }^{-1}\right)\end{array}$} \\
\hline & 2015 & 2016 & 2015 & 2016 & 2015 & 2016 & 2015 & 2016 & 2015 & 2016 \\
\hline $\mathrm{T}_{1}$ & 44.93 & 42.23 & 44.50 & 54.40 & 3.23 & 4.93 & 113.13 & 138.00 & 397.23 & 487.87 \\
\hline $\mathrm{T}_{3}$ & 53.51 & 56.33 & 74.07 & 78.40 & 6.28 & 6.80 & 209.63 & 232.59 & 683.11 & 681.27 \\
\hline $\mathrm{T}_{4}$ & 52.48 & 52.09 & 73.02 & 77.33 & 6.03 & 6.73 & 225.67 & 230.97 & 679.83 & 738.13 \\
\hline $\mathrm{T}_{5}$ & 52.01 & 55.73 & 73.11 & 82.33 & 6.19 & 6.70 & 230.33 & 233.20 & 720.89 & 779.40 \\
\hline $\mathrm{T}_{6}$ & 56.57 & 58.67 & 75.40 & 88.93 & 6.24 & 6.82 & 254.37 & 257.00 & 750.40 & 805.87 \\
\hline $\mathrm{T}_{7}$ & 55.46 & 57.37 & 73.87 & 85.77 & 6.23 & 6.80 & 252.00 & 255.93 & 733.67 & 802.87 \\
\hline $\mathrm{T}_{8}$ & 63.31 & 64.37 & 82.87 & 101.47 & 6.80 & 7.10 & 289.99 & 302.39 & 817.73 & 874.27 \\
\hline $\mathrm{T}_{9}$ & 61.10 & 62.80 & 81.14 & 97.47 & 6.39 & 6.53 & 281.00 & 286.33 & 789.40 & 835.00 \\
\hline $\mathrm{T}_{10}$ & 62.32 & 63.53 & 79.89 & 98.67 & 6.25 & 7.03 & 284.66 & 297.67 & 786.40 & 825.27 \\
\hline $\mathrm{T}_{11}$ & 56.33 & 58.47 & 74.93 & 92.33 & 6.30 & 7.00 & 251.00 & 262.60 & 748.40 & 809.53 \\
\hline $\mathrm{T}_{12}$ & 59.88 & 60.68 & 81.20 & 94.60 & 6.33 & 6.53 & 267.13 & 280.07 & 797.39 & 862.53 \\
\hline C.D. at $5 \%$ & 5.01 & 4.07 & 11.26 & 8.27 & 1.37 & 0.93 & 11.95 & 9.91 & 14.57 & 19.51 \\
\hline
\end{tabular}

${ }^{*} \mathrm{~T}_{1}$ : Control; $\mathrm{T}_{2}: 100 \%$ recommended dose of N (RDN) through farmyard manure (FYM) @ $25.0 \mathrm{t} \mathrm{ha}^{-1} ; \mathrm{T}_{3}: 100 \%$ RDN through vermicompost (VC) @ 9.3 t ha-1 $; \mathrm{T}_{4}: 100 \%$ RDN through neem cake (NC) @ $7.4 \mathrm{tha}^{-1} ; \mathrm{T}_{5: 75 \%} \mathrm{RDN}$ + $25 \%$ RDN through FYM @ $6.2 \mathrm{tha}^{-1} ; \mathrm{T}_{6}: 75 \% \mathrm{RDN}+25 \% \mathrm{RDN}$ through VC @ $2.3 \mathrm{tha}^{-1} ; \mathrm{T}_{7}: 75 \% \mathrm{RDN}+25 \%$ RDN through NC @ $1.8 \mathrm{tha}^{-1} ; \mathrm{T}_{8}: 50 \% \mathrm{RDN}+25 \%$ RDN through FYM @ $6.2 \mathrm{t} \mathrm{ha}^{-1}+25 \% \mathrm{RDN}$ through VC @ $2.3 \mathrm{t} \mathrm{ha}^{-1} ; \mathrm{T}_{9}: 50 \% \mathrm{RDN}+25 \% \mathrm{RDN}$ through FYM @ $6.2 \mathrm{t} \mathrm{ha}^{-1}+25 \% \mathrm{RDN}$ through NC @ $1.8 \mathrm{t} \mathrm{ha}^{-1} ; \mathrm{T}_{10}: 50 \%$ RDN + 25\% RDN through VC @ $2.3 \mathrm{t} \mathrm{ha}^{-1}+25 \%$ RDN through NC @ $1.8 \mathrm{t} \mathrm{ha}^{-1} ; \mathrm{T}_{11}: 25 \% \mathrm{RDN}+25 \% \mathrm{RDN}$ through FYM @ $6.2 \mathrm{t} \mathrm{ha}^{-1}+25 \% \mathrm{RDN}$ through VC @ $2.3 \mathrm{t} \mathrm{ha}^{-1}+25 \% \mathrm{RDN}$ through NC @ $1.8 \mathrm{t} \mathrm{ha}^{-1} ; \mathrm{T}_{12}$ : full recommended dose of NPK (150 kg N : $50 \mathrm{~kg} \mathrm{P}_{2} \mathrm{O}_{5}: 100 \mathrm{~kg} \mathrm{~K}_{2} \mathrm{O} \mathrm{ha}^{-1}$ ) through inorganic fertilizer. 
Table.4 Dry weight of leaves and tubers, dry matter and specific gravity of tubers as affected by integrated nutrient management

\begin{tabular}{|c|c|c|c|c|c|c|c|c|}
\hline \multirow[t]{2}{*}{ Treatments* } & \multicolumn{2}{|c|}{$\begin{array}{c}\text { Dry weight of } \\
\text { leaves }\left(\mathrm{g} \text { plant }{ }^{-1}\right)\end{array}$} & \multicolumn{2}{|c|}{$\begin{array}{c}\text { Dry weight of } \\
\text { tubers }\left(\mathrm{g} \text { plant }{ }^{-1}\right)\end{array}$} & \multicolumn{2}{|c|}{$\begin{array}{c}\text { Dry matter } \\
(\%)\end{array}$} & \multicolumn{2}{|c|}{$\begin{array}{l}\text { Specific gravity } \\
\left(\mathrm{g} \mathrm{cc}^{-1}\right)\end{array}$} \\
\hline & 2015 & 2016 & 2015 & 2016 & 2015 & 2016 & 2015 & 2016 \\
\hline $\mathrm{T}_{1}$ & 15.83 & 19.96 & 81.45 & 84.07 & 15.31 & 15.40 & 1.048 & 1.055 \\
\hline $\mathrm{T}_{2}$ & 38.94 & 40.69 & 86.22 & 94.12 & 16.85 & 16.91 & 1.068 & 1.061 \\
\hline $\mathrm{T}_{3}$ & 46.33 & 46.93 & 98.25 & 109.23 & 17.71 & 17.83 & 1.071 & 1.072 \\
\hline $\mathrm{T}_{4}$ & 41.96 & 42.32 & 94.13 & 100.79 & 16.39 & 16.28 & 1.069 & 1.064 \\
\hline $\mathrm{T}_{5}$ & 44.58 & 45.21 & 103.29 & 108.19 & 17.87 & 17.15 & 1.077 & 1.078 \\
\hline $\mathrm{T}_{6}$ & 52.06 & 53.20 & 110.16 & 121.49 & 17.27 & 17.01 & 1.092 & 1.093 \\
\hline $\mathrm{T}_{7}$ & 44.47 & 45.78 & 108.44 & 113.20 & 18.33 & 17.34 & 1.090 & 1.090 \\
\hline $\mathrm{T}_{8}$ & 57.27 & 59.86 & 121.50 & 130.18 & 18.84 & 18.81 & 1.093 & 1.093 \\
\hline $\mathrm{T}_{9}$ & 46.46 & 51.45 & 115.22 & 121.78 & 16.38 & 16.98 & 1.083 & 1.091 \\
\hline $\mathrm{T}_{10}$ & 47.11 & 49.53 & 118.66 & 120.92 & 17.53 & 17.32 & 1.085 & 1.084 \\
\hline $\mathrm{T}_{11}$ & 47.77 & 48.28 & 116.49 & 119.08 & 16.95 & 16.98 & 1.090 & 1.084 \\
\hline $\mathrm{T}_{12}$ & 40.76 & 43.84 & 112.47 & 114.52 & 17.64 & 17.10 & 1.079 & 1.086 \\
\hline C.D. at $5 \%$ & 5.23 & 6.57 & 4.16 & 7.70 & 1.01 & 0.8 & 0.002 & 0.003 \\
\hline
\end{tabular}

* $\mathrm{T}_{1}$ : Control; $\mathrm{T}_{2:}$ 100\% recommended dose of $\mathrm{N}(\mathrm{RDN})$ through farmyard manure (FYM) @ $25.0 \mathrm{t} \mathrm{ha}^{-1} ; \mathrm{T}_{3}: 100 \%$ RDN through vermicompost (VC) @ $9.3 \mathrm{t} \mathrm{ha}^{-1} ; \mathrm{T}_{4}: 100 \% \mathrm{RDN}$ through neem cake (NC) @ $7.4 \mathrm{t} \mathrm{ha}^{-1} ; \mathrm{T}_{5:}$ 75\% RDN + $25 \%$ RDN through FYM @ $6.2 \mathrm{t} \mathrm{ha}^{-1} ; \mathrm{T}_{6}: 75 \%$ RDN + 25\% RDN through VC @ $2.3 \mathrm{t} \mathrm{ha}^{-1} ; \mathrm{T}_{7}: 75 \% \mathrm{RDN}+25 \%$ RDN through NC @ $1.8 \mathrm{t} \mathrm{ha}^{-1} ; \mathrm{T}_{8}: 50 \% \mathrm{RDN}+25 \% \mathrm{RDN}$ through FYM @ $6.2 \mathrm{t} \mathrm{ha}^{-1}+25 \% \mathrm{RDN}$ through VC @ $2.3 \mathrm{t} \mathrm{ha}^{-1} ; \mathrm{T}_{9}: 50 \% \mathrm{RDN}+25 \% \mathrm{RDN}$ through FYM @ $6.2 \mathrm{tha}^{-1}+25 \% \mathrm{RDN}$ through NC @ $1.8 \mathrm{t} \mathrm{ha}^{-1} ; \mathrm{T}_{10}: 50 \%$ RDN + 25\% RDN through VC @ $2.3 \mathrm{t} \mathrm{ha}^{-1}+25 \%$ RDN through NC @ $1.8 \mathrm{t} \mathrm{ha}^{-1} ; \mathrm{T}_{11}: 25 \% \mathrm{RDN}+25 \% \mathrm{RDN}$ through FYM @ $6.2 \mathrm{t} \mathrm{ha}^{-1}+25 \% \mathrm{RDN}$ through VC @ $2.3 \mathrm{t} \mathrm{ha}^{-1}+25 \% \mathrm{RDN}$ through NC @ $1.8 \mathrm{t} \mathrm{ha}^{-1} ; \mathrm{T}_{12}$ : full recommended dose of NPK $\left(150 \mathrm{~kg} \mathrm{~N}: 50 \mathrm{~kg} \mathrm{P}_{2} \mathrm{O}_{5}: 100 \mathrm{~kg} \mathrm{~K}_{2} \mathrm{O}^{-1}\right)$ through inorganic fertilizer.

Table.5 Yield and tuber trait as influenced by integrated nutrient management

\begin{tabular}{|c|c|c|c|c|c|c|c|c|}
\hline \multirow[t]{2}{*}{ Treatments* } & \multicolumn{2}{|c|}{$\begin{array}{l}\text { Number of } \\
\text { tuber/plant }\end{array}$} & \multicolumn{2}{|c|}{$\begin{array}{c}\text { Number of tuber } \\
/ \text { plot }\end{array}$} & \multicolumn{2}{|c|}{ Total yield $\left(\mathrm{kg} \mathrm{plot}^{-1}\right)$} & \multicolumn{2}{|c|}{ Total yield (t ha $\left.{ }^{-1}\right)$} \\
\hline & 2015 & 2016 & 2015 & 2016 & 2015 & 2016 & 2015 & 2016 \\
\hline $\mathrm{T}_{1}$ & 7.44 & 7.45 & 850 & 805 & 42.15 & 42.16 & 32.52 & 32.53 \\
\hline $\mathrm{T}_{2}$ & 9.37 & 9.41 & 1012 & 1038 & 47.49 & 47.94 & 36.65 & 36.99 \\
\hline $\mathrm{T}_{3}$ & 10.97 & 11.04 & 1237 & 1250 & 52.41 & 53.02 & 40.44 & 40.91 \\
\hline $\mathrm{T}_{4}$ & 10.68 & 10.87 & 1185 & 1221 & 51.12 & 51.26 & 39.44 & 39.55 \\
\hline $\mathrm{T}_{5}$ & 10.89 & 10.94 & 1176 & 1180 & 52.49 & 52.93 & 40.50 & 40.84 \\
\hline $\mathrm{T}_{6}$ & 12.54 & 12.56 & 1355 & 1359 & 53.13 & 53.33 & 41.00 & 41.15 \\
\hline $\mathrm{T}_{7}$ & 10.79 & 10.89 & 1166 & 1183 & 51.89 & 51.85 & 40.04 & 40.01 \\
\hline $\mathrm{T}_{8}$ & 14.65 & 14.66 & 1582 & 1591 & 54.23 & 54.80 & 41.84 & 42.28 \\
\hline $\mathrm{T}_{9}$ & 11.46 & 11.47 & 1242 & 1269 & 51.20 & 52.00 & 39.51 & 40.13 \\
\hline $\mathrm{T}_{10}$ & 11.28 & 11.33 & 1219 & 1226 & 52.54 & 52.75 & 40.54 & 40.70 \\
\hline $\mathrm{T}_{11}$ & 11.07 & 11.13 & 1196 & 1207 & 53.70 & 53.89 & 41.43 & 41.58 \\
\hline $\mathrm{T}_{12}$ & 11.50 & 11.53 & 1177 & 1189 & 51.02 & 51.55 & 39.37 & 39.78 \\
\hline C.D. at $5 \%$ & 1.39 & 1.07 & 64.42 & 70.91 & 4.03 & 4.00 & 3.26 & 3.34 \\
\hline
\end{tabular}

* $\mathrm{T}_{1}$ : Control; $\mathrm{T}_{2:} 100 \%$ recommended dose of $\mathrm{N}(\mathrm{RDN})$ through farmyard manure (FYM) @ $25.0 \mathrm{t} \mathrm{ha}^{-1} ; \mathrm{T}_{3}: 100 \%$ RDN through vermicompost (VC) @ $9.3 \mathrm{t} \mathrm{ha}^{-1} ; \mathrm{T}_{4}: 100 \% \mathrm{RDN}$ through neem cake (NC) @ $7.4 \mathrm{t} \mathrm{ha}^{-1} ; \mathrm{T}_{5}: 75 \% \mathrm{RDN}$ $+25 \%$ RDN through FYM @ $6.2 \mathrm{tha}^{-1} ; \mathrm{T}_{6}: 75 \% \mathrm{RDN}+25 \% \mathrm{RDN}$ through VC @ $2.3 \mathrm{t} \mathrm{ha}^{-1} ; \mathrm{T}_{7}: 75 \% \mathrm{RDN}+25 \%$ RDN through NC @ $1.8 \mathrm{t} \mathrm{ha}^{-1} ; \mathrm{T}_{8}: 50 \% \mathrm{RDN}+25 \% \mathrm{RDN}$ through FYM @ $6.2 \mathrm{t} \mathrm{ha}^{-1}+25 \% \mathrm{RDN}$ through VC @ $2.3 \mathrm{t} \mathrm{ha}^{-1} ; \mathrm{T}_{9}: 50 \% \mathrm{RDN}+25 \% \mathrm{RDN}$ through FYM @ $6.2 \mathrm{t} \mathrm{ha}^{-1}+25 \% \mathrm{RDN}$ through NC @ $1.8 \mathrm{t} \mathrm{ha}^{-1} ; \mathrm{T}_{10}: 50 \%$ $\mathrm{RDN}+25 \% \mathrm{RDN}$ through VC @ $2.3 \mathrm{t} \mathrm{ha}^{-1}+25 \% \mathrm{RDN}$ through NC @ $1.8 \mathrm{t} \mathrm{ha}^{-1} ; \mathrm{T}_{11}: 25 \% \mathrm{RDN}+25 \% \mathrm{RDN}$ through FYM @ $6.2 \mathrm{t} \mathrm{ha}^{-1}+25 \% \mathrm{RDN}$ through VC @ $2.3 \mathrm{t} \mathrm{ha}^{-1}+25 \% \mathrm{RDN}$ through NC @ $1.8 \mathrm{t} \mathrm{ha}^{-1} ; \mathrm{T}_{12}$ : full recommended dose of NPK ( $\left.150 \mathrm{~kg} \mathrm{~N}: 50 \mathrm{~kg} \mathrm{P}_{2} \mathrm{O}_{5}: 100 \mathrm{~kg} \mathrm{~K}_{2} \mathrm{O} \mathrm{ha}^{-1}\right)$ through inorganic fertilizer.

Stimulation of root growth (initiation and proliferation of root hair), increased root biomass, enhanced plant growth and development have been reported with the 
application of vermicompost, because of the presence of humic acids (Suh et al., 2014).

Qualities of tubers were studied in terms of dry matter content, specific gravity, dry weight of tubers/plant along with dry weight of leaves (Table 4). Significant reduction in dry weight of leaves and tubers/plant, dry matter content and specific gravity were recorded with $100 \%$ recommended nitrogen through inorganic fertilizer comparing to mixture of inorganic along with organic sources. Maximum dry weight of leaves and tubers/plant, dry matter content and specific gravity were found with the treatment $50 \%$ $\mathrm{RDN}+25 \% \mathrm{RDN}$ through FYM + 25\% RDN through VC compare to another combination. The superiority of quality characters obtained under integrated use of $50 \%$ RDN through inorganic fertilizers and remaining $50 \% \mathrm{RDN}$ through organic sources (FYM+VC) could be attributed to the beneficial effect of combined use of vermicompost plus farmyard manure and chemical fertilizer in precise proportions that led to increased nutrient availability through enhance microbial activity, conversion from unavailable to available forms and improved physical chemical and biological conditions of soil (Singh and Kushwah, 2006). Manure application had appositive effect on potato productivity, number of tuber/plant and per plot, total yield/plot and total yield per hectare varied significantly with levels of organic manure (Table 5), increasing number of tuber/plant and per plot as well as total tuber yield was obtained with the application of 50\% RDN + $25 \%$ RDN through FYM $+25 \%$ RDN through VC but it was statistically at par with $50 \%$ $\mathrm{RDN}+25 \% \mathrm{RDN}$ through FYM + 25\% RDN through $\mathrm{NC}$ or $50 \% \mathrm{RDN}+25 \% \mathrm{RDN}$ through VC $+25 \%$ RDN through NC. Single application of FYM, VC and NC also recorded significantly higher tuber yield and its traits than control. The fertility levels of all the organic sources of nutrients gave higher tuber yield as compared to RDN. It was also observed that organic manures showed beneficial effect on tuber yield as the result of Chettri et al., (2002). In addition to these ingredients, FYM also supplies plant growth hormones, enzymes, antibiotics and vitamins to the crop plants Bhawalker (1991). The result showed that the increase in tuber number and tuber yield was due to vermicompost has high porosity, aeration drainage and water-holding capacity which effects on tuber development and total yield Joshi et al., (2015).

Based on the two-year data it may be concluded that potato requires adequate nutrition under North Indian condition that may be achieved by judicious and balanced use of organic and inorganic sources of nutrients. The application of $50 \%$ recommended dose of $\mathrm{N}$ through inorganic fertilizer and remaining 50\% recommended dose of $\mathrm{N}$ through organic manures (25\%FMY plus 25\%vermicompost) are recommendable practices for higher growth characters, tubers quality and tuber yield. A significant effect of the using vermicompost as compared to FYM and neem cake is shown.

\section{References}

Albiach R., Canet R., Pomares F., Ingelmo F. (2000). Microbial biomass content and enzymatic activities after application of organic amendments to a horticultural soil. Bioresource Technology,75 :43-48.

Arancon N.Q., Edwards C.A., Bierman P., Metzger J.D., Lee S., Welch C. (2003). Effects of vermicomposts 3 on growth and marketable fruits of field-grown tomatoes, peppers and strawberries. Pedobiologia,47 :731-735.

Arora S. (2008). Balanced nutrition for sustainable crop production. Krishi World (Pulse of Indian Agriculture). pp. 
1-5.

Atiyeh R.M., Lee S., Edwards C.A., Arancon N.Q., Metzger J.D. (2002). The influence of humic acids derived from earth worm processed organic wastes on plant growth. Bioresource Technology, 84: 7-14.

Atul Jayapal, Swadija O.K., Anju V.S. (2016). Impact of organic management on yield, quality and economics of Chinese potato (Plectranthus rotundifolius). Indian Journal of Agronomy, 61(1): 127-130.

Banu S., Thiyagarajan T.M., Malarvizhi P. (2007). Effect of graded levels of fertilizers on quality aspects of potato. Potato Journal, 34 (3-4): 242-44.

Bhawalker U.S. (1991) Vermiculture technology for LEISA. In: Seminar on low external input sustainable agriculture. Amsterdam, Netherland

Chettri M., Mondal S.S., Roy B. (2002). Influence of potassium and sulphur with or without FYM on growth, productivity and disease index of potato in soils. Journal of Indian Potato Association, 29(1-2): 61-65.

Diacono M., Montemurro F. (2010). Longterm effects of organic amendments on soil fertility: Reviews in Agronomy for Sustainable Development, 30(2): 401422.

Edmeades D.C. (2003). The long-term effects of manures and fertilizers on soil productivity and quality. Reviews in Nutrient Cycling in Agroecosystems, 66: 165-180.

FAO (2014). World Reference Base for Soil Resources 2006. World Soil Resources Report 103. Food and Agriculture Organization, Rome, pp. 145.

Gawish Ragaa A., Ali F.A., Midan Sally A., Taha M.A. (2012). Effect of organic compost and mineral $\mathrm{N}$ fertilizers applied individually or in different combination rates along with seaweed extract on vegetative growth, tuber development, dry weight and growth analysis of potato plants. Menofia Journal of Agricultural Research, 37(1): 183-201.

Joshi R., Singh J., Vig A.P. (2015). Vermicompost as an effective organic fertilizer and biocontrol agent: effect on growth, yield and quality of plants. Reviews in Environmental Science and Bio/Technology, 14: 137-159.

Kumar M., Baishaya L.K., Ghosh D.C., Gupta V.K., Dubey S.K., Anup Das, Patel D.P. (2012). Productivity and soil health of potato (Solanum tuberosum L.) field as influenced by organic manures, inorganic fertilizers and biofertilizers under high altitudes of Eastern Himalayes. Journal of Agricultural Science, 4(5): 223-234.

Najar I.A., Khan A.B. (2013). Effect of vermicompost on growth and productivity of tomato (Lycopersicon esculentum) under field conditions. Acta Biologica Malaysiana, 2(1):12-21.

Panse V.G., Sukhatme, P.V. (1985). Statistical Methods for Agricultural Workers. (II Ed.). ICAR Publication, Delhi.

Reintam E., Koster T. (2006). The role of chemical indicators to correlate some Estonian soils with WRB and soil taxonomy criteria. Geoderma, 136: 199209.

Scott G.J., Suarez V. (2012). The rise of Asia as the center of global potato production and some implications for industry. Potato Journal, 39(3-4): 1-22.

Singh R., Sharma R.R., Tyagi S.K. (2007). Pre-harvest foliar application of calcium and boron influences physiological disorders, fruit yield and quality of strawberry (Fragaria xananassa Duch.). Scientia Horticulturae, 112: 215-220.

Singh, S.P., Kushwah V.S. (2006). Effect of 
integrated use of organic and inorganic sources of nutrients on potato (Solanum tuberosum L.) production. Indian Journal of Agronomy, 51(3): 236-38.

Suh H.Y., Yoo K.S., Suh S.G. (2014). Tuber growth and quality of potato (Solanum tuberosum L.) as affected by foliar or soil application of fulvic and humic acids. Horticulture Environment and Biotechnology, 55(3):183-189.

Thiele G., Theisen K., Bonierbale M., Walker T. (2010). Targeting the poor and hungry with potato science. Potato Journal, 37(3-4): 75-86.

Tomati U., Grappelli A., Galli E. (1988). The hormone like effect of earthworm casts on plant growth. Biology and Fertility of Soils, 5:288-294.

Upadhayay N.C., Singh J.P. (2003). The Potato (Production and utilization in Sub-Tropics) Edited by SM Paul Khurana, JS. Minhas and SK Pandey. Published by Mehta Publishers, A16(East), Naraina II, New Delhi110028, India.

Warman P.R., AngLopez M.J. (2010). Vermicompost derived from different feedstocks as a plant growth medium. Bioresource Technology, 101:44794483.

\section{How to cite this article:}

Mohamed Taha, T.P. Malik, A.K. Bhatia and Sumit Deswal. 2017. Tuber Growth and Quality of Potato var. Kufri Bahar as Affected by FYM, Vermicompost and Neem Cake under Western Haryana Conditions. Int.J.Curr.Microbiol.App.Sci. 6(12): 4118-4125. doi: https://doi.org/10.20546/ijcmas.2017.612.473 